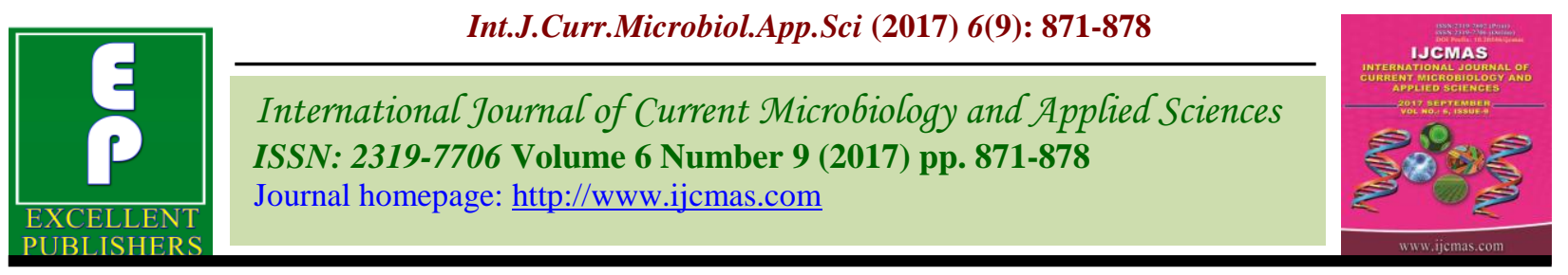

Original Research Article

https://doi.org/10.20546/ijcmas.2017.609.105

\title{
Mapping and Current Available Nutrient Deficiencies in Soils of Chittoor District Soils of Andhra Pradesh, India
}

\author{
E. Govardhan ${ }^{1 *}$, M.C. Patnaik ${ }^{2}$ and P. Surendra Babu ${ }^{3}$ \\ ${ }^{1}$ Department of soil science and Agri. Chemistry, PJTSAU, Rajendra Nagar, \\ Hyderabad 500 030, India \\ ${ }^{2}$ AICRP on Micronutrients, PJTS Agricultural University, Rajendra Nagar, Hyd-500 030, India \\ ${ }^{3}$ Director of ARI farm, Hyderabad 500 030, India \\ *Corresponding author
}

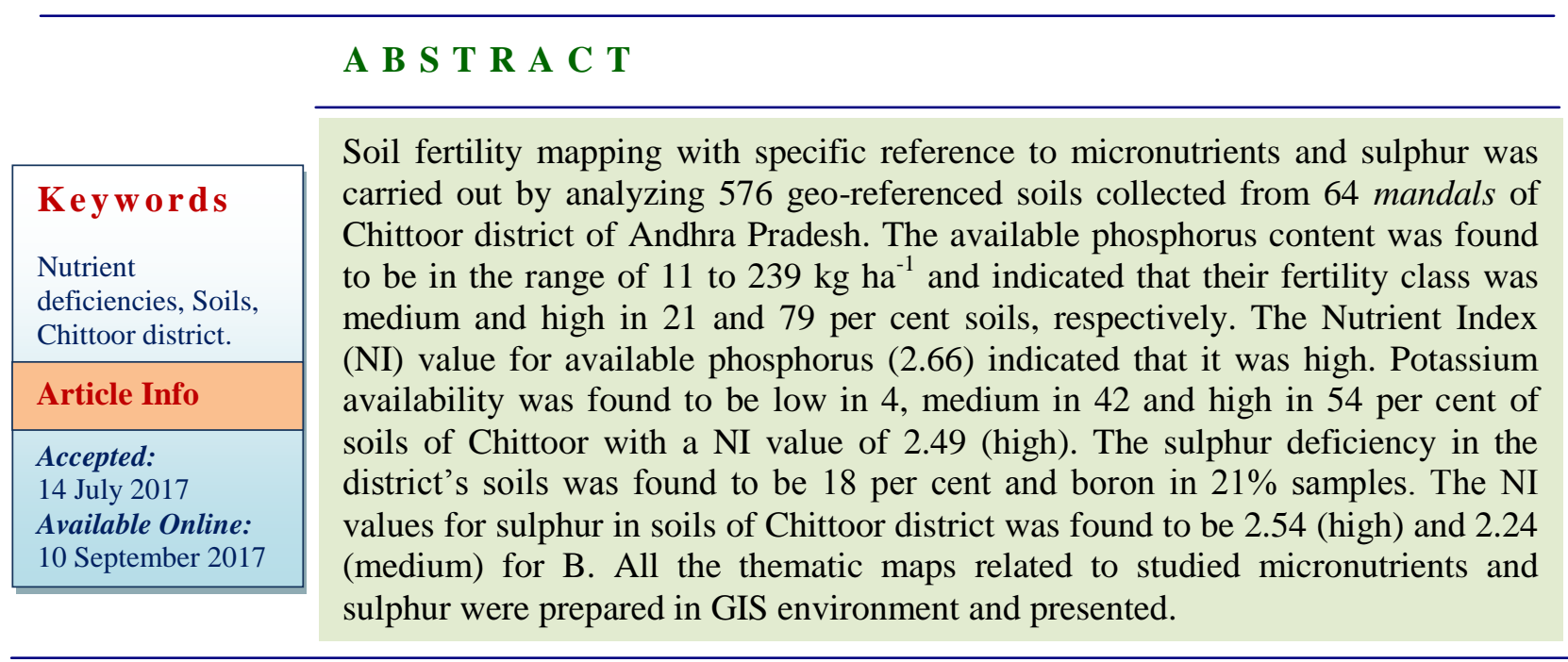

\section{Introduction}

Soil plays a major role in determining the sustainable productivity of an agro ecosystem. The sustainable productivity of a soil mainly depends upon its ability to supply essential nutrients to the crop. The deficiency of micronutrients has become a major constraint in optimizing crop productivity and soil sustainability (Bingham, 1982; Chesnin and Yien, 1950). The availability of micronutrients in soil is dependent on the parent material, pedogenic process and soil management which may promote, in some cases a reduction of cationic micronutrients content. Reduction in native levels of micronutrients in soils due to continuous shipping away of micronutrients without replenishment has been a cause of concern for all the stakeholders. It is well known that optimum plant growth and crop yields depend upon plant available micronutrients to the crop not on their total concentration.

Realising its more important role in the country's agricultural production, outflow of exchequer for importing costly fertilizers and to help farmers to prevent imbalanced use of fertilizers in their fields, the Government of India, through Department of Agriculture and 
Co-Operation started an ambitious project 'GPS and GIS based Soil Fertility Maps' in 2010. This project was intended to help in making precise fertilizer recommendations for the farmers of the country. Nineteen out of 26 states in the country have been covered so far under this project where in both major and micronutrients of soils are analysed for their fertility status (www.iiss.nic.in and pib.nic.in/newsite). In the former state of Andhra Pradesh (which was re-organised in 2014 as Telangana and residuary Andhra Pradesh states), such work was taken up in 10 districts (Ramana Reddy et al., 2013) and the efforts are being made to complete the left over work in the newly re-organised two states.

The validity and usefulness of generated soil fertility maps of an area depends upon the intensity of sampling done, methods of analysis and classes of fertility adopted, time lapse since its preparation and the backed-up fertilizer prescription accuracy for adoption by farmers. It is a herculian task to map the fertility of entire cultivated area of the country having about 138.35 million holdings at one time due to logistics involved and the under usage of logistics developed as the reassessment of fertility is needed only after 2 to 3 years. Therefore, a viable approach is to concurrently carryout the soil fertility mapping on rotation basis in terms of space and time by encompassing all holdings and farming community.

\section{Materials and Methods}

\section{Soil sampling, analysis and preparation of deficiency maps}

The methodology adopted was, about 7 to 10 soil samples were collected from each mandal. The samples were collected from cultivated lands on grid basis; as a result, the spatial coverage of survey area will be more. Accordingly, 576 soil samples were collected from 64 mandals of 66 mandals present in the district. The depth of the soil sampling was 0 $15 \mathrm{~cm}$. The soil samples collected were processed and analysed for $\mathrm{P}^{\mathrm{H}}, \mathrm{EC}$ and $\mathrm{OC}$. Nutrient index value calculated from the proportion of soils under low, medium and high available nutrient categories, as represented by

$\mathrm{NIV}=\frac{\left[\left(\mathrm{PH}^{*} 3\right)+\left(\mathrm{PM}^{*} 2\right)+\left(\mathrm{PL}{ }^{*} 1\right)\right]}{100}$

The index values are rated in to various categories viz., high (>2.33), medium (1.66 2.33) and low $(<1.66)$ for fertility rating [Ramamurthy and Bajaj 1969]. Simple correlations were carried out between the soil available micronutrients and soil properties to determine the relationship between these parameters using standard procedures at central computer facility of the university using in built software.

\section{Available phosphorus}

The available phosphorus in soil samples was extracted by Olsen's method and was estimated by colorimeter method and is expressed as $\mathrm{kg} \mathrm{P}_{2} \mathrm{O}_{5} \mathrm{ha}^{-1}$. The $\mathrm{P}$ content in the extract was colorimtrically (Model ECIL GS5701 SS) determined as per procedure given by Watanabe and Olsen (1965) using ascorbic acid.

\section{Available potassium}

The available potassium in soil samples was determined by neutral normal ammonium acetate method using flame photometer (Jackson, 1973) and expressed as $\mathrm{kg} \mathrm{K}_{2} \mathrm{O} \mathrm{ha}{ }^{-1}$.

\section{Available sulphur}

The available sulphur in soil samples was extracted with $0.15 \% \quad \mathrm{CaCl}_{2}$ solution (Williams and Steinbergs, 1961). Five grams 
of soil was shaken with $25 \mathrm{ml}$ of $0.15 \% \mathrm{CaCl}_{2}$ for 30 minutes in a shaker. The extract was filtered through Whatman no.42 filter paper and the sulphur was determined by turbidometric method and the absorbance of this solution was read by using spectrophotometer at $420 \mathrm{~nm}$ (Chesnin and Yien, 1950) and expressed as $\mathrm{mg} \mathrm{kg}^{-1}$

\section{Available boron}

It was determined following the method of Berger and Troug (1945) and details are presented below;

Azomethine- $\mathrm{H}$ was prepared by dissolving $0.45 \mathrm{~g}$ of Azomethine- $\mathrm{H}$ in $100 \mathrm{ml}$ of 1 per cent ascorbic acid. The buffer solution was prepared by dissolving $250 \mathrm{~g}$ of ammonium acetate and $15 \mathrm{~g}$ of Di-Sodium salt of EDTA (Ethylene Diamine Tetra Acetic acid) in 400 $\mathrm{ml}$ of double distilled water. All the reagents were dissolved and $125 \mathrm{ml}$ of acetic acid was added to the solution and mixed thoroughly (Bingham, 1982).

\section{Results and Discussion}

\section{Available phosphorus (kg ha $\left.{ }^{-1}\right)$}

The available phosphorus status of soils of Chittoor district ranged from 11 to $239 \mathrm{~kg} \mathrm{ha}^{-1}$ with mean of $73 \mathrm{~kg} \mathrm{ha}^{-1}$. As per phosphorus fertility ratings given by Muhr et al., (1965), the extent of soils in Chittoor district falling under low, medium and high category was 9, 17 and 74 per cent, respectively.

All soils of seventeen mandals in Chittoor district totalling to 140 analyzed for available phosphorus was found to be high. They are Peeleru, Kaligiri, Chowdepalli, Gudipala, Pakala, Puthuru, Renigunta, Bucchinadu kandriga, Thotembeedu, KVB puram, Rompicharla, Ramachandrapuram, Chandragiri, Chinnagotikallu, Yerravaripalem and Mulakalacheruvu mandals. These mandals constituted 26.5 per cent of total mandals of the district. The soils of only one mandal i.e. of Gurramkonda registered highest under low category of phosphorus availability to an extent of 50 per cent (5 samples out of 10). The other mandals wherein their soils registering perceptible low available phosphorus were Ramasamudram (43\%), Gudipalli and Srikalahasti (37\% each) (Fig. 1).

High and continuous application of phosphatic fertilizers might have resulted in occurance of high phosphorus soils in the district. Such build up in available phosphorus was also noticed in the soils of Amritsar district of Punjab, Haveri district of Karnataka and Coimbatore of Tamil Nadu during fertility mapping by Sharma et al., (2008), Mamladesai et al., (2012) and Padmavathi et al., (2014), respectively.

\section{Available potassium $\left(\mathrm{kg} \mathrm{ha}^{-1}\right)$}

The available potassium determined in soils of Chittoor district ranged from 25 to $777 \mathrm{~kg}$ $\mathrm{ha}^{-1}$ with mean of $337 \mathrm{~kg} \mathrm{ha}^{-1}$. Out of this 576 samples, three and eleven (54\%) were found to be fall under high potassium fertility class followed by 42 per cent ( 241 no) in medium fertility category. Very few samples in the district (24) have registered low available potassium status. These results indicate that majority of the soils in the district fall in the medium to high potassium fertility category.

Among the mandals, the entire soils analyzed for available potassium were found to be high in potassium fertility in Veduru kuppam, Bucchinadu kandriga and Thotambeedu mandals. The soils of twenty mandals of 64 present in Chittoor district recorded medium NI values while the rest have fallen under NI value of potassium fertility. The NI value for potassium status was found to be 2.49 and is depicted in figure 2. 
Table.1 Categorization of mandals of Chittoor district based on extent of sulphur deficiency in soils for prioritization of fertilizer usage decisions

\begin{tabular}{|l|l|l|l|l|}
\hline \multicolumn{2}{|c|}{ 0-10 } & \multicolumn{1}{c|}{$\mathbf{1 1 - 2 5}$} & \multicolumn{1}{c|}{$\mathbf{2 6 - 5 0}$} & \multicolumn{1}{c|}{$\mathbf{5 1 - 7 5}$} \\
\hline \multicolumn{2}{|c|}{ Mandals } & \multicolumn{1}{c|}{$\mathbf{8}$ Mandals } & \multicolumn{1}{c|}{$\mathbf{1 6}$ Mandals } & \multicolumn{1}{c|}{ Mandals } \\
\hline Bangaru Palem & Gangadhara Nelluru & Chadumu & Chinnagottikallu & Bucchinadu Kandriga \\
\hline Bireddy & K.V. B. Puram & Chandragiri & Choudapelli & Irpedu \\
\hline Chittoor & Karvetinagar & Gudipalli & Gurram Konda & Ramachandrapuram \\
\hline Gangavaram & Nangalapuram & Kothakota & Kalkada & Rompicharla \\
\hline Gudipala & Narayanavanam & Nagiri & Kammavaripally & Thottambeedu \\
\hline Irala & Nindra & Peddamandem & Kuravalakota & \\
\hline Kaligiri & Pala Samudram & Puthuru & Madanapalli & \\
\hline Kuppam & Penumooru & Tambalapalle & Mulkalacheruvu & \\
\hline Pakala & Pichatoor & & Nemman Palli & \\
\hline Palamaneru & Poothalapattu & & Peeleru & \\
\hline Pedda Panjani & Pulicharla & & PTM & \\
\hline Punganuru & Renigunta & & Rama Samudram & \\
\hline Ramakuppam & Sathyavedu & & Srirangarajapuram & \\
\hline Santhipuram & Srikalahasti & & Vayalpadu & \\
\hline Somula & Vadamala Peta & & Veduru Kuppam & \\
\hline Tavanam Palle & Varadaiah Palem & & Yerravaripalem & \\
\hline Venkatagiri Kota & Vijayapuri & & & \\
\hline Yedamari & & & & \\
\hline
\end{tabular}

PSD: Per cent samples deficient

Table.2 Categorization of mandals of Chittoor district based on extent of boron deficiency in soils for prioritization of fertilizer usage decisions

\begin{tabular}{|l|l|l|l|l|l|}
\hline \multicolumn{2}{|c|}{ 0-10 } & \multicolumn{1}{c|}{$\mathbf{1 1 - 2 5}$} & \multicolumn{1}{c|}{$\mathbf{2 6 - 5 0}$} & \multicolumn{1}{c|}{$\mathbf{5 1 - 7 5}$} & \multicolumn{1}{c|}{$>$ (75 } \\
\hline 32 Mandals & \multicolumn{1}{c|}{$\mathbf{1 0}$ Mandals } & \multicolumn{1}{c|}{ 14 Mandals } & \multicolumn{1}{c|}{ Mandals } & 2 Mandals \\
\hline Bangaru Palem & Chandragiri & Chadumu & Bucchinadu Kandriga & Kalkada & Kaligiri \\
\hline Bireddy & Chinnagottikallu & Chittoor & Gangavaram & Mulkalacheruvu & Kothakota \\
\hline Choudapelli & Gurram Konda & K.V. B. Puram & Irala & Pichatoor & \\
\hline Gangadhara Nelluru & Kuravalakota & Nemman Palli & Irpedu & Tavanam Palle & \\
\hline Gudipala & Madanapalli & Pakala & Karvetinagar & Thottambeedu & \\
\hline Gudipalli & Nagiri & Palamaneru & PTM & Veduru Kuppam & \\
\hline Kammavaripally & Nangalapuram & Pedda Panjani & Ramakuppam & & \\
\hline Kuppam & Narayanavanam & Puthuru & Renigunta & & \\
\hline Peeleru & Nindra & Ramachandrapuram & Somula & & \\
\hline Penumooru & Pala Samudram & Yerravaripalem & Srikalahasti & & \\
\hline Poothalapattu & Peddamandem & & Srirangarajapuram & & \\
\hline Punganuru & Pulicharla & & Vadamala Peta & & \\
\hline Rama Samudram & Rompicharla & & Vayalpadu & & \\
\hline Santhipuram & Sathyavedu & & Vijayapuri & & \\
\hline Venkatagiri Kota & Tambalapalle & & & & \\
\hline Yedamari & Varadaiah Palem & & & & \\
\hline
\end{tabular}


Fig.1 Phosphorus fertility status in soils of Chittoor District, A.P.

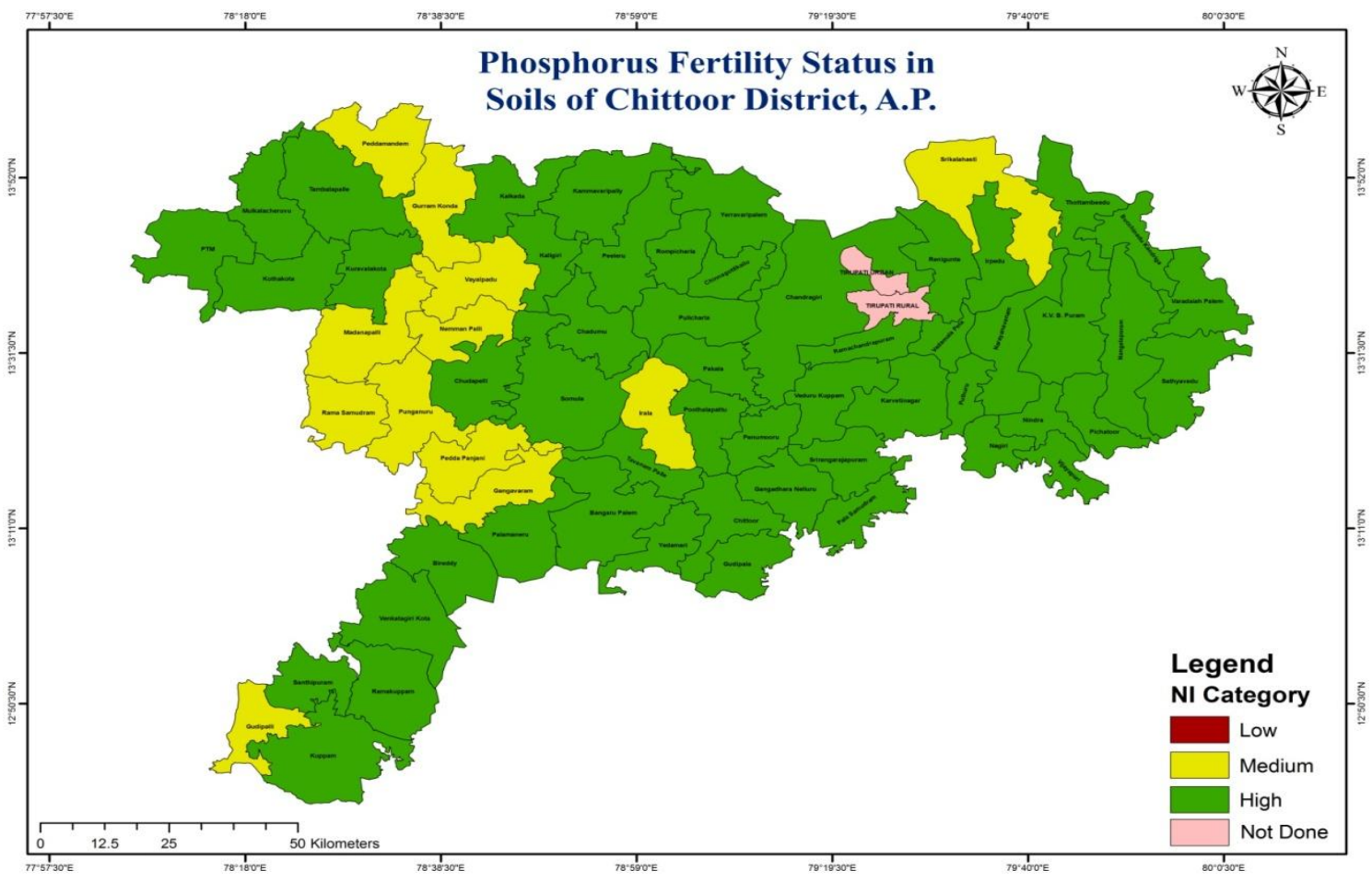

Fig.2 Potassium fertility status in soils of Chittoor District, A.P

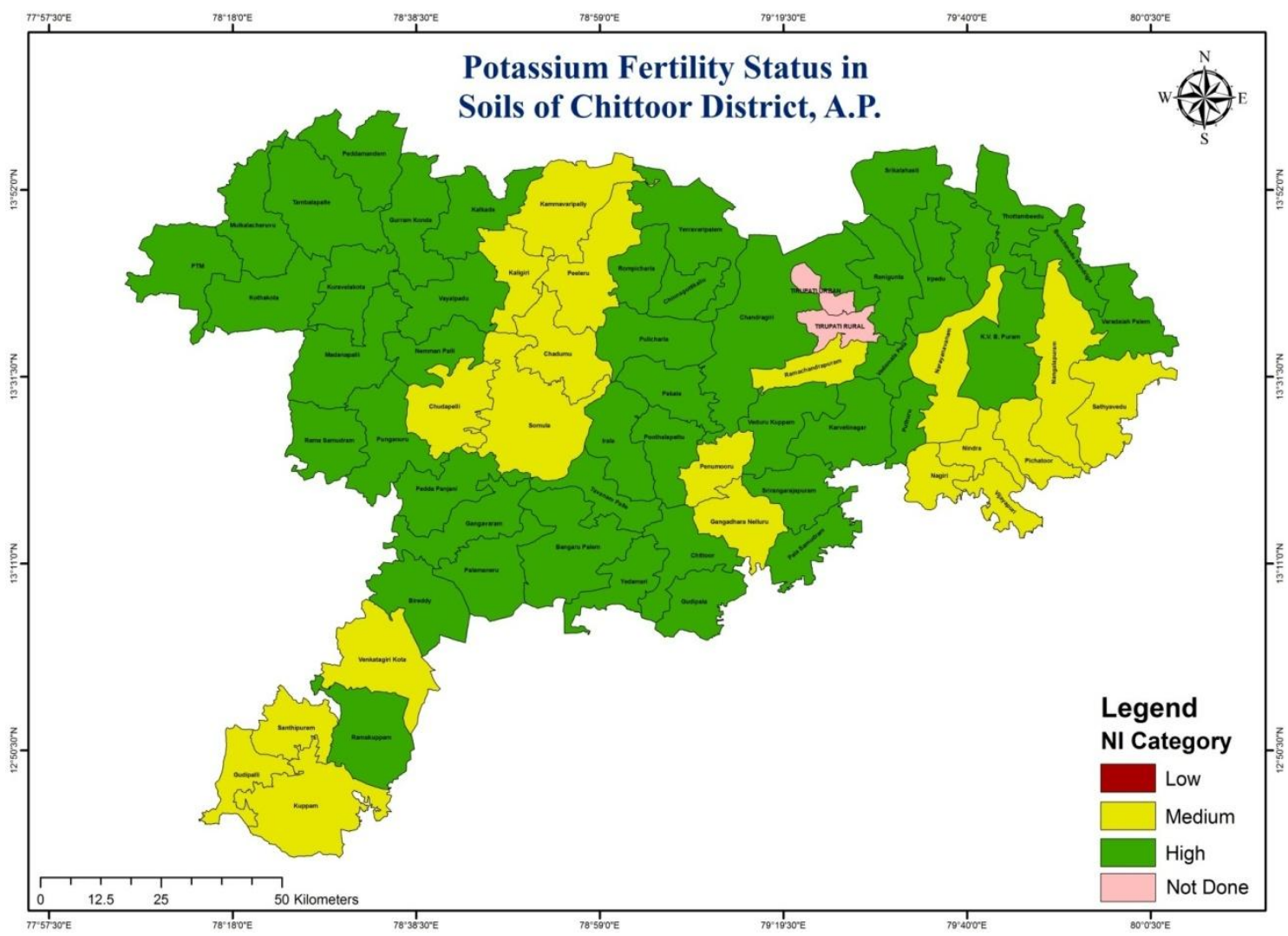


Fig.3 Sulphur fertility status in soils of Chittoor District, A.P.

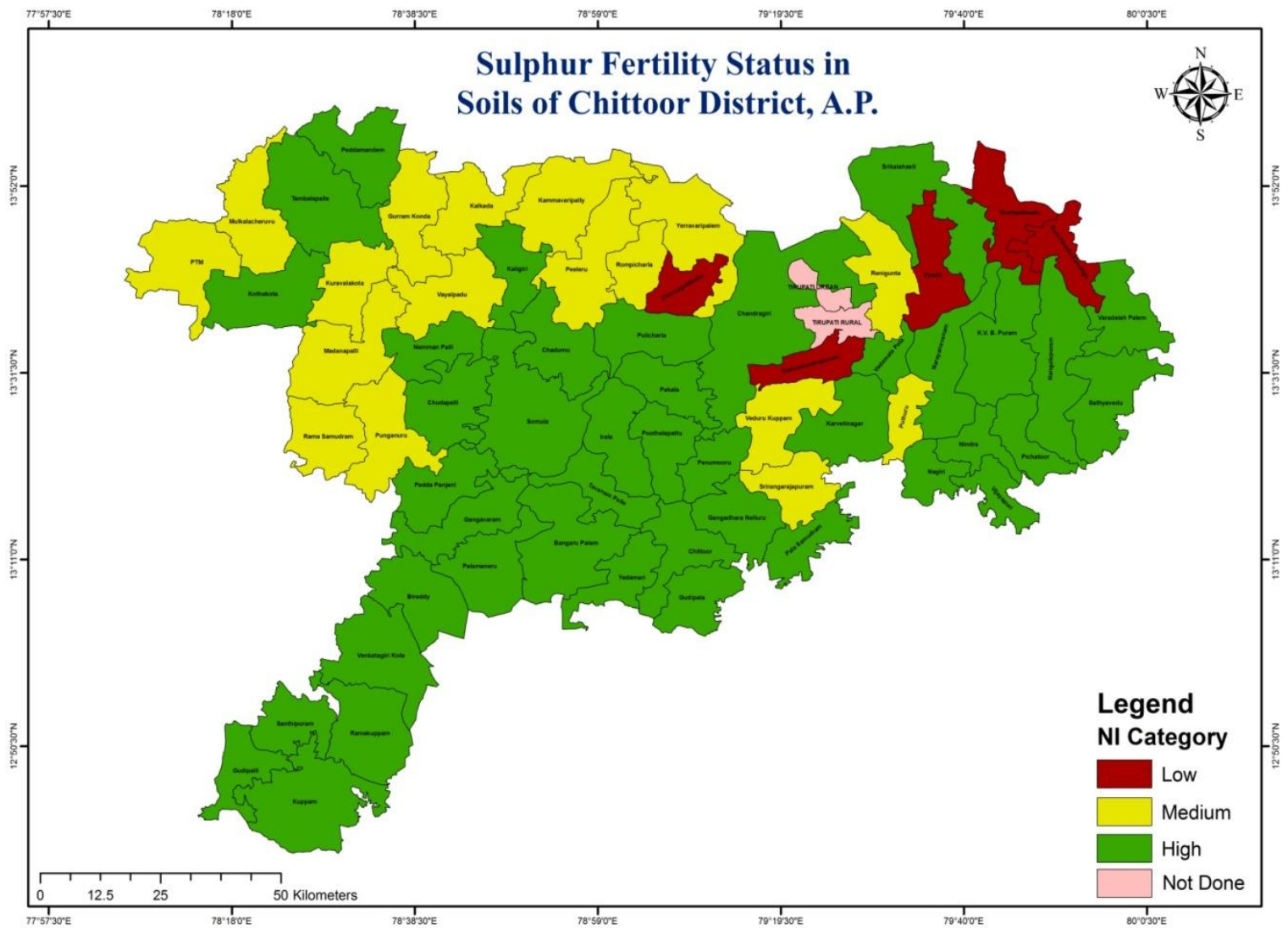

Fig.4 Boron fertility status in soils of Chittoor District, A.P.

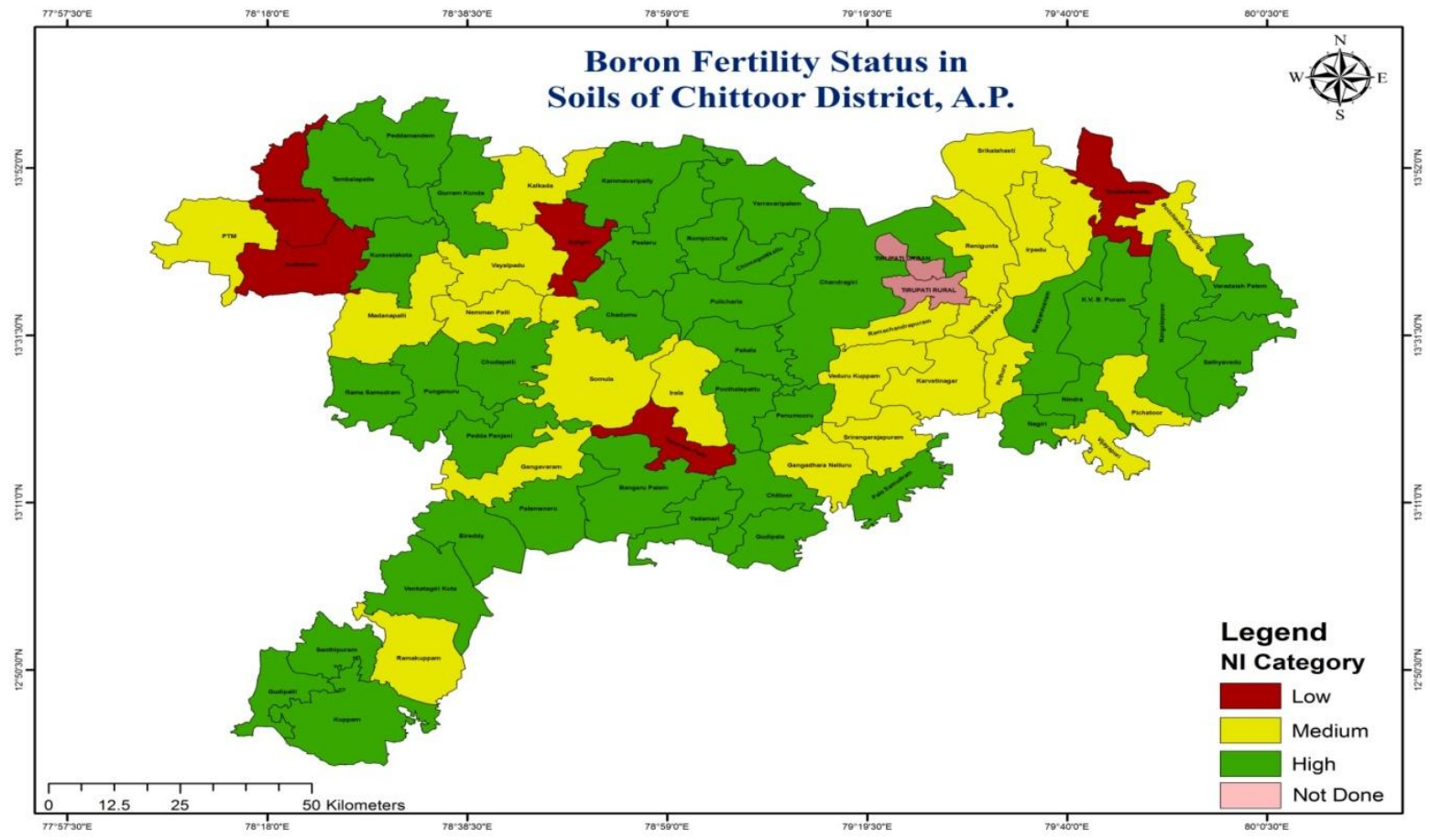


Variation in available potassium across the soils of different districts was noticed by several workers (Rezo et al., 2007; Sharma et al., 2009; Pulakeshi et al., 2012; Dhamak et $a l ., 2014$ ) and was attributed to variation in mineralogical compositions.

\section{Available sulphur}

It is observed from the table 1 that 18 per cent (104 no) analyzed soils in Chittoor district were found to be deficient in available sulphur. Its content ranged from 3.5 to 194 $\mathrm{mg} \mathrm{kg}{ }^{-1}$ with mean of $29.4 \mathrm{mg} \mathrm{kg}^{-1}$.

The perusal of data indicated that the mean sulphur content was in the range of 8.6 to 58.1 mg kg-1 with in the mandals. Likewise, the extent of sulphur deficiency within the mandals ranged from 10 to 71 per cent among their soils. As many as 26 mandals out of 64 in the district have not registered any sulphur deficiency in their soils. The NI values for available sulphur in different mandals of the district ranged from 1.29 (Buchinadu kandriga) to 3.0. Only 5 mandals of the district registered low NI values and they are irpedu, Bucchinadu kandriga, Thotembeedu, Ramachandrapuram and Chinnagottikallu. The overall NI value for sulphur of Chittoor district was found to be high (2.54). The map generated for sulphur NI is depicted in figure 3. In an earlier study restricted to limited areas of Chittoor district, Munaswamy (1991) and Venkatesu (1993) reported sulphur deficiency to an extent of 50 per cent by analyzing few soil samples.

\section{Available boron}

The available boron was found to be deficient in 21 per cent of 576 soil samples analyzed from Chittoor district. The extent of boron deficiency in soils of individual mandals ranged from 0 to 100 per cent. Its content in the district soils ranged from 0.15 to $2.12 \mathrm{mg}$ $\mathrm{kg}^{-1}$ soil with a mean value of $0.91 \mathrm{mg} \mathrm{kg}^{-1}$ (Table 2). The mean hot water extractable boron in soils of different mandals ranged from 0.38 (Kaligiri mandal) to $1.59 \mathrm{mg} \mathrm{kg}^{-1}$ (Nagiri). The boron deficiency status map generated for soils of Chittoor is depicted in figure 4 .

Soil nutrients maps would be highly useful in improving our understanding regarding native and extent of nutrient problems and this can aid in developing appropriate nutrients management strategies leading to better yield and environmental stewardship, which ultimately would be helpful in determining their relationship with animal and human health.

\section{References}

Bingham, F.T., 1982. Boron, In: Methods of soil analysis, part 2. Chemical and micro biological properties (A.L. Page Ed), 431-448. American Society of Agronomy. Madison. WI. USA.

Chesnin, L., and Yien C H 1950 Turbidometric determination of available sulphates. Soil Science Society of America Proceedings. 14:149-151.

Dhamak, A.L., Meshram, N. A and Waikar, S. L.2014. Comparative Studies on Dynamics Soil Properties and Forms of Sulphur in Oilseed Growing Soils of Ambajogai Tahsil of Beed District. IOSR Journal of Agriculture and Veterinary Science (IOSR-JAVS). 7(12): 98-102.

Jackson, M.L., 1973. Soil chemical analysis An advanced course, Second Edition, University of Wisconsin, Madison, USA.

Mamaledesai, N.R., Patil, P.L., Chandrashekar, C.P., Potdar, M.P., Astaputre, S.A., Desai, S.R and Hanumantha Swamy.2012. Assessment 
of nutrients status in Cotton growing area of Haveri district in northern transitional zone of Karnataka and response of cotton to applied nutrients at different yield targets. AgroInformatics and Precision Agriculture.42-46.

Munaswamy, V., 1981. Secondary nutrient status of groundnut growing soils of Chittoor district of Andhra Pradesh. M.Sc (Ag). Thesis submitted to Andhra Pradesh Agricultural University, Hyderabad.

Olsen, S.R., Cole, C.V., Watanade, F.S and Dean, L.A. 1954. Estimation of available phosphorus in soil by extraction with sodium bicarbonate. Cri. U.S. Dep. Agric. 939.

Padmavathi, T., Muthukrishnan, R., Mani and S. Sivasamy, R.2014. Assessment of Soil Physic-Chemical Properties and Macronutrients Status in Coimbatore District of Tamil Nadu Using GIS Techniques. Trends in biosciences. 7(19):2879-2881.

Pulakeshi, H. B. P., Patil, P. Dasog, G. S., Radder, B. M. B., Bidari, I and C. P. Mansur. Mapping of nutrients status by geographic information system (GIS) in Mantagani village under northern transition zone of Karnataka. Karnataka Journal of Agricuktural Sciences.25 (3): 332-335.

Ramamoorthy, B., and Bajaj, J.C. (1969) Available N, P and $\mathrm{K}$ status of Indian soils. Fertilizers News 14, 24-26.

Rego, T.J., Sahrawat, K.L. Wani, S.P. and Pardhasaradhi, G. 2007. Widespread deficiencies of sulphur, boron and zinc in dryland soils of the Indian semi-arid tropical soils: on farm crop responses. Journal of Plant Nutrition. 30: 15691583.

Sharma, J.C., and Chaudhary, K. 2007. Vertical Distribution of Micronutrient cations in relation to soil characteristics in lower Shiwaliks of Solan district in North-West Himalayas. Journal of the Indian Society of Soil Science. 55(1): 40-44.

Venkatesu, T., 1993. Distribution and availability of cationic Micronutrients in Groundnut grown sandy soils of Nellore district.M.sc thesis submitted to, Andhra Pradesh Agricultural University, Hyderabad.

Williams, C.H., and Steinbergs, A. 1961. The evaluation of plant available sulphur in soils. Plant and Soil. 17:276-278.

\section{How to cite this article:}

Govardhan, E., M.C. Patnaik and Surendra Babu, P. 2017. Mapping and Current Available Nutrient Deficiencies in Soils of Chittoor District Soils Of Andhra Pradesh. Int.J.Curr.Microbiol.App.Sci. 6(9): 871-878. doi: https://doi.org/10.20546/ijcmas.2017.609.105 